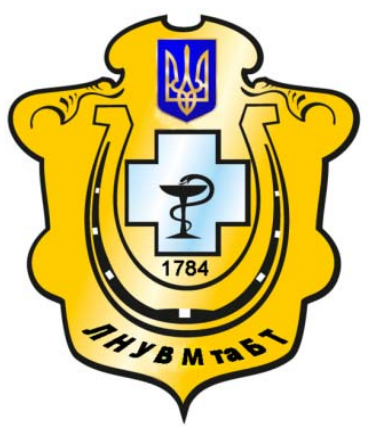

Науковий вісник Львівського національного університету ветеринарної медицини та біотехнологій імені С.3. Гжицького

Scientific Messenger of Lviv National University of Veterinary Medicine and Biotechnologies named after S.Z. Gzhytskyj

doi:10.15421/nvlvet6831

ISSN 2413-5550 print

ISSN $2518-1327$ online

$\underline{\text { http://nvlvet.com.ua/ }}$

УДК 637.5

\title{
Внесення колагенвмісних сумішей в фаршеві системи
}

В.М. Пасічний, М.М. Полумбрик

pasww1@ukr.net, manefaiv@mail.ru

Національний університет харчових технологій, вул. Володимирська, 68, м. Київ, 01601, Украӥна

В статті приведено обтрунтування найбільш рачіональних иляхів введення додаткових джерел тваринних білків в фаршеві системи, які призначені для виготовлення ковбас вареної групи. Наведено результати впливу попередньо гідратованих та сухих білкових стабілізаторів на функціонально-технологічні та органолептичні показники м'ясних виробів. Аргументовано доиільність додавання колагеновмісних структуроутворювачів саме в гелеподібній формі при складанні фариу на промислових підприємствах. Встановлено, щчо внесення гелеподібних білоквмісних композицій в фаршеві системи забезпечує вищі показники органолептичної оцінки готових виробів, ніж при виготовленні м'ясних продуктів з додаванням порошкоподібних стабілізаторів. Результати, отримані після проведення досліджень, можуть бути аргументом для зміни технології внесення структуроутворювачів в фаршеві емульсії.

Ключові слова: ковбаси, внесення, сполучнотканинний білок, фаршева система, стабілізатор, фарш, колаген, білкозин.

\section{Внесение коллагенсодержащих смесей в фаршевые системы}

\author{
В.Н. Пасичный, М.Н. Полумбрик
}

pasww1@ukr.net, manefaiv@mail.ru

Национальный университет пищевых технологий, ул. Владимирская, 68, г. Киев, 01601, Украина

В статье приведены обоснования наиболее рациональных путей введения дополнительных источников животных белков в фаршевые системы, которые предназначены для изготовления колбас вареной группы. Представлены результаты влияния предварительно гидратированных и сухих белковых стабилизаторов на функиионально-технологические и органолептические показатели мясных изделий. Аргументировано необходимость внесения коллагенсодержащих структурообразователей именно в гелеобразной форме при составлении фарша в куттере на промышленных предприятиях. Установлено, что внесение гелеобразных белоксодержащих композиций в фаршевые системы обеспечивает более высокие показатели органолептической оценки готовых изделий, чем при изготовлении мясных продуктов с использованием порошкообразных стабилизаторов. Результаты, полученные после проведения исследований, могут быть основой для изменения технологии внесения структурообразователей в фаршевые эмульсии.

Ключевые слова: колбасы, внесение, соединительнотканный белок, фариевая система, стабилизатор, фари, коллаген, белкозин.

\section{Collagen containing mixtures impact on sensory properties of chicken forcemeat systems}

\author{
V.M. Pasichniy, M.M. Polumbryk \\ pasww1@ukr.net,manefaiv@mail.ru
}

Citation:

Pasichniy, V.M., Polumbryk, M.M. (2016). Collagen containing mixtures impact on sensory properties of chicken forcemeat systems. Scientific Messenger LNUVMBT named after S.Z. Gzhytskyj, 18, 2(68), 150-152. 
National University of Food Technologies,

Volodymyrska Str., 68, Kyiv, 01601, Ukraine

Sensory changes of forcemeat systems as well as boiled sausages, that caused by collagenous proteins of animal origin have been determined. It was found that the most technologically reasonable form of collagen utilization at the forcemeat formation in the cutter was form of gel. It was resulted in rise of sensory properties of the final sausages in compare with products made from dry solids. These results can be used in order to change hydrocolloids insertion technology into forcemeat emulsions.

The quality of meat products concluded by indicators in humidity, plasticity, volohozvyazuvalnoyi capacity, the concentration of hydrogen ions in the finished product. With the introduction of hydrocolloids in powder decreased functional and technological and organoleptic deterioration. Thus, the addition of hydrocolloids in dry form in the formation of minced with other prescription components led to what hydrocolloids not dissolved due to lack of water. Obviously, the moisture quickly absorbed most active substances volohopohlynalnymy recipes - meat protein and carbohydrates. Adding stabilizer gel led to its uniform distribution in the stuffing, finished products thus had excellent organoleptic properties. Studies have shown expediency of protein stabilizers in the form of gels in ground beef recipes. Analysis of comprehensive research confirms that the current adjustment of production technology of cooked sausages beneficial to the overall distribution of constituents and has considerable technological advantages compared to classical approaches.

Key words: sausages, binding protein, minced meat system, stabilizer, nanocomposite, collagen, silicagel, bilkozine.

\section{Вступ}

3 метою збільшення обсягів ковбасного виробництва, підвищення, збереження і стабілізації якості продукту поряд з основною сировиною виробники ковбасних виробів дедалі частіше застосовують різні добавки, в тому числі білкові, які за своїми функціональними властивостями наближаються до м'язових білків (Kochetkova, 2000). Найбільший інтерес представляють білкові препарати, які володіють достатнім ступенем розчинності у водній фазі фаршу, гелеутворюючими і емульгуючими властивостями. Одним 3 таких $\epsilon$ «Білкозин» - колагеновий яловичий білок, який забезпечує стабільність технологічного процесу. Крім того, збільшує кількість тваринного білка в м'ясних виробах, підвищує якісні показники і поживну цінність готової продукції. Цей компонент сприяє зниженню втрат вологи при термообробці та зберіганні (Vetrov and Azmer, 2009).

«Білкозин» здатний виявляти свої функціональні властивості як окремо, так і в поєднанні 3 іншими компонентами, такими, як рослинні, тваринні білки, круп'яні наповнювачі i карагенани. Нейтральний рівень $\mathrm{pH}$ і запах дозволяють змішувати його з різними інгредієнтами на різних етапах виробництва ковбасних виробів. Слід відзначити, що застосування колагенового яловичого білка при виготовленні варених ковбасних виробів дозволяє стабілізувати частинки жиру, які фіксуються в набухлій білковій структурі та у вигляді стабільної емульсії утримує жирові бульбашки і воду (Kushnir, 2008).

Однією з умов ефективності застосування гідроколоїдів у харчових системах є їх повне розчинення, що залежить від їх хімічної природи. Навіть у невеликій кількості гідроколоїди значно покращують та зберігають структуру готових продуктів, надаючи їм при цьому покращені органолептичні характеристики. Вони виступають у якості стабілізаторів та вологоутримуючих агентів. Всі технологічні функції гідроколоїдів обумовлені особливостями хімічної будови та фізико-хімічними властивостями (Bazarnova, 2005).

3 метою забезпечення максимального впливу білоквмісних стабілізаторів на якісні показники готових ковбасних виробів вареної групи, були досліджені різні способи внесення гідроколоїдів на основі «Білкозину» в фаршеві системи.

\section{Матеріал і методи досліджень}

В технології м'ясних фаршів були випробувані наступні способи внесення білкових стабілізаторів (БС): внесення гідроколоїдів в сухому вигляді в фаршеву емульсію та попереднє розчинення гідроколоїдів у тій кількості води, яка передбачена рецептурою з наступним внесенням в систему.

Визначення вмісту вологи висушуванням проводилось 3 використанням прискореного методу. Концентрацію іонів водню досліджували з використанням $\mathrm{pH}$-метра-340. Значення вологозв'язуючої здатності ковбасних виробів та їх пластичності отримали за допомогою методу пресування. Органолептичну оцінку готового продукту проводили за 5-ти бальною шкалою.

\section{Результати та їх обговорення}

В якості білкового стабілізатора (БС) була обрана композиція, яка володіє високими емульгуючими властивостями (Pasichnyi et al., 2015), з наступним складом: сухий яловичий білок «Білкозин» $60 \%$, суха молочна сироватка 20\%, карбоксиметилцелюлоза 5\%, камідь гуарова 10\%, камідь ксантанова 5\%. Рецептурний склад варених ковбасних виробів наведений в табл. 1.

Табличя 1

Рецептурний склад ковбасних виробів

\begin{tabular}{|l|c|}
\hline \multicolumn{1}{|c|}{ Інгредієнти } & Кількість, \% \\
\hline Стегно куряче & 70 \\
\hline БС & 15 \\
\hline Соя гідролізована & 15 \\
\hline Кремнезем & 0,1 \\
\hline Сіль, \% на 100 г & 2,1 \\
\hline Нітрит, г на 100 г & 0,005 \\
\hline Вода & 30 \\
\hline Суміш спецій «Сосиски франкфуртські» & 1,0 \\
\hline
\end{tabular}


Під час фаршескладання в першому випадку БС вносився в м'ясну систему у вигляді порошку (Зразок 1), в другому випадку - у вигляді гелю $з$ подальшим додаванням допоміжної сировини (Зразок 2). Функціонально-технологічні показники готових ковбасних виробів наведено в табл. 2.
3 даних, наведених в таблиці можна побачити, що вироби $з$ внесення гелеподібного БС володіють вищими значеннями пластичності та вологозв'язувальної здатності, ніж вироби $з$ додаванням БС у вигляді порошку.

Функціонально-технологічні властивості змодельованих ковбасних виробів

\begin{tabular}{|c|l|c|c|c|c|}
\hline \multicolumn{2}{|c|}{ Показник } & $\mathrm{pH}$ & Вміст вологи, \% & Пластичність, см ${ }^{2} / \Gamma$ & В3За, \% \\
\hline \multirow{3}{*}{ Зразок 1} & 1 доба & 6,4 & $76,3 \pm 1,7$ & $8,4 \pm 0,13$ & $82,0 \pm 0,58$ \\
\cline { 2 - 6 } & 5 доба & 6,5 & $75,3 \pm 1,9$ & $8,0 \pm 0,11$ & $81,4 \pm 0,62$ \\
\cline { 2 - 6 } & 13 доба & 6,7 & $76,8 \pm 2,0$ & $8,2 \pm 0,14$ & $79,7 \pm 0,54$ \\
\hline \multirow{3}{*}{ Зразок 2} & 1 доба & 6,6 & $76,8 \pm 1,7$ & $8,9 \pm 0,12$ & $84,8 \pm 0,61$ \\
\cline { 2 - 6 } & 5 доба & 6,6 & $75,9 \pm 1,6$ & $8,3 \pm 0,16$ & $83,9 \pm 0,67$ \\
\cline { 2 - 6 } & 13 доба & 6,6 & $76,2 \pm 1,8$ & $8,7 \pm 0,12$ & $83,6 \pm 0,59$ \\
\hline
\end{tabular}

На Рис. 1 наведена діаграма показників органолептичної оцінки варених сосисок, виготовлених $з$ додаванням порошко- та гелеподібного білкового стабілізатора. При сенсорному аналізі сосисок встановлено: батони з чистою, сухою поверхнею, без пошкоджень оболонки, напливів фаршу та злипань. На розрізі фарш однорідного рожевого кольору, пружної консистенції. Запах властивий даному виду продукту із легким ароматом прянощів. Смак приємний, достатньо солоний, сторонніх присмаків не відчувається. Проте вироби з внесенням сухого БС відрізнялися від сосисок $з$ додаванням гелеподібного БС більш пухкою текстурою. На нашу думку, це пов'язано $з$ недостатнім набуханням і розчиненням компонентів БС.

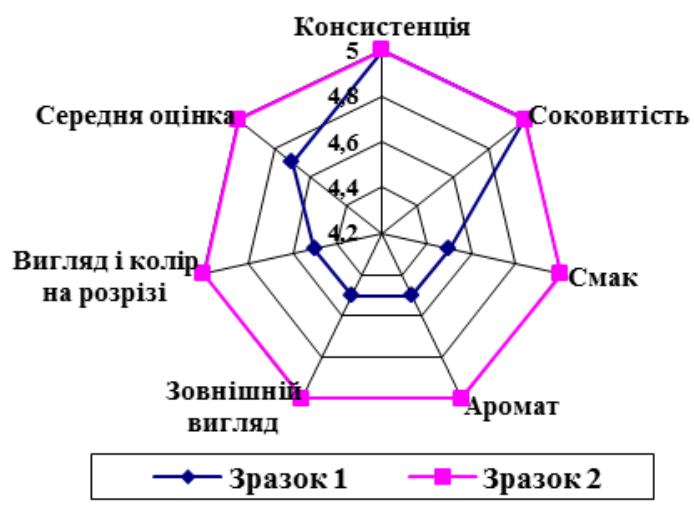

Рис. 1. Органолептична оцінка варених ковбасних виробів 3 додаванням білкового стабілізатора у вигляді порошку та гелю

\section{Висновки}

Про якість м'ясних виробів робили висновок за показниками вологості, пластичності, вологозвязувальної здатності, концентрації іонів водню в готових виробах. Із внесенням гідроколоїдів у вигляді порошку спостерігалося зниження функціонально-технологічних та погіршення органолептичних показників. Так, додавання гідроколоїдів в сухому вигляді при формуванні фаршу разом 3 іншими рецептурним компонентами приводило до того, що гідроколоїди не розчинялися через недостатню кількість води. Очевидно, волога швидше поглиналася найбільш активними вологопоглинальними речовинами рецептури - білками м'яса та вуглеводами. Внесення стабілізатору у вигляді гелю призводило до рівномірного розподілення його у фарші, готові вироби при цьому мали відмінні органолептичні показники. Проведені дослідження показали доцільність внесення білкових стабілізаторів у вигляді гелів в рецептуру м'ясних фаршів. Аналіз комплексних досліджень підтверджує, що коригування технології виробництва сучасних варених ковбасних виробів сприятливо позначається на загальному розподіленні складових компонентів та має значні технологічні переваги, порівняно $з$ класичними підходами.

Перспективи подальших досліджень. Перспективним $є$ проведення досліджень, направлених на вивчення взаємодії жирів та гідроколоїдів в багатокомпонентних системах - рецептурах фаршевих виробів.

\section{Бібліографічні посилання}

Bazarnova, Y.G. (2005). Primenenie naturalnykh hydrocolloidov dlya stabilizatsii pischevykh productov. Pischevyje ingredienty: syrie I dobavki. 2, 84-87 (in Russian).

Vetrov, V.S., Azmer, A.N. (2009). Sovremennyje aspecty proizvodstva myasnykh farshevykh productov / V.S. Vetrov, // Pischevaja promyshlennost: nauka I tekhnologii, 3(5), 25-30 (in Russian).

Kochetkova, A.A. (2000). Pischevyje hydrocolloidy: teoreticheskije zametki. Pischevyje ingredienty: Syrje i dobavki. 1, 10-11 (in Russian).

Kushnir, Y. (2008). Hydrocolloidy. Producty \& ingredienty. 5, 106-107 (in Russian).

Pasichnyi, V.M. Khomenko, Y.O., Polumbryk, M.M., Nevodiuk, I.V. (2015). Zastosuvannya collagenovogo tvarynnogo bilka «Bilkozyn» v tekhnologii varenykh kovbas. Naukovyi visnyk LNUVMB im. S.Z.Gzhytskogo. tekhnichni nauky. Seriya «Kharchovi tekhnologii». 17, 1(61), 80-843 (in Ukrainian).

Стаття надійшла до редакиії 4.10.2016 